\title{
Differential impact of anthropogenic pressures on Caspian Sea ecoregions
}

\author{
Matteo Lattuada *, Christian Albrecht, Thomas Wilke \\ Department of Animal Ecology \& Systematics, Justus Liebig University, Heinrich-Buff-Ring 26-32, IFZ, Giessen, Germany
}

\section{ARTICLE INFO}

\section{Keywords:}

Caspian Sea

Cumulative environmental assessment

Anthropogenic impact

Ecoregions

Endemic species

\begin{abstract}
A B S T R A C T
Over the past decades, overall ecological conditions in the Caspian Sea have deteriorated. However, a comprehensive understanding of lake-wide spatial differences in anthropogenic pressures is lacking and the biological consequences of human impacts are poorly understood. This paper therefore aims at assessing the individual and combined effects of critical anthropogenic pressures on the Caspian Sea ecoregions. First, cumulative pressure scores were calculated with a cumulative environmental assessment (CEA) analysis. Then, the individual contribution of anthropogenic pressures was quantified. Finally, ecoregion-specific differences were assessed. The analyses show that both cumulative and individual pressure scores are unevenly distributed across the Caspian Sea. The most important individual pressures are invasive species, chemical pollution and poaching. This uneven distribution of pressure scores across Caspian Sea ecoregions creates new challenges for future conservation strategies, as different ecoregions usually require different conservation measures.
\end{abstract}

\section{Introduction}

The Caspian Sea is a large lake renowned for its diverse aquatic fauna (Zenkevitch, 1963; Karpinsky, 2005). However, over the last decades, many of its unique species assemblages have increasingly suffered from environmental (e.g., water-level fluctuations, salinity changes) and anthropogenic pressures (e.g., oil extraction, overfishing, introduction of invasive species). As a consequence, the overall ecosystem health has deteriorated and many endemic species have become regionally or globally extinct (Dumont, 1995; Karpinsky, 2005; Zonn, 2005; Zarbaliyeva et al., 2016; Mammadov et al., 2016; Wesselingh et al., 2019).

Unfortunately, our knowledge about the impact of environmental and anthropogenic factors on the native biodiversity in the Caspian Sea is largely biased towards few key stressors related to natural water-level fluctuations and human activities, such as fishery and mineral extraction (Malinovskaja et al., 1998; Agah et al., 2007; Malinovskaya and Zinchenko, 2010, 2011; Khodorevskaya et al., 2014; Yanina, 2014; Latypov, 2015; Mammadov et al., 2016; Poorbagher et al., 2017). Moreover, most previous human impact studies in the Caspian Sea are restricted to coastal areas (Nasrabadi et al., 2011; Aliyeva et al., 2013; Bastami et al., 2014), individual countries (Aliyeva et al., 2013; Dmitrieva et al., 2013; Bastami et al., 2014; Yancheshmeh et al., 2014;
Mashroofeh et al., 2015; Varnosfaderany et al., 2015) or selected target species (Bickham et al., 1998; Agah et al., 2007; Dmitrieva et al., 2013; Ermolin and Svolkinas, 2016; Poorbagher et al., 2017). Therefore, a comprehensive understanding of lake-wide spatial differences in combined and individual pressures is lacking and the biological consequences of human impacts are poorly understood.

A potential solution to this problem arises from the fact that the Caspian Sea has been divided into ten ecoregions based on ecologically relevant environmental variables (Fendereski et al., 2014). These ecoregions generally correspond to the distribution ranges of many endemic, native and invasive species (Fendereski et al., 2014), and they allow for a coarse latitudinal and vertical (bathymetrical) assessment of anthropogenic pressures. Thus, ecoregion-specific environmental analyses might be a suitable approach to obtain a basic understanding of the spatially-explicit impact of anthropogenic pressures on Caspian Sea biota.

In this paper, we therefore estimated cumulative and individual pressure scores of critical anthropogenic pressures for the ten Caspian Sea ecoregions by using a cumulative environmental assessment (CEA) analysis.

Our specific goals were to:

1) infer the spatial distribution of cumulative pressure scores, i.e. the sum of individual pressure score intensities multiplied by specified weighting variables (see formula in Section 2.2.),

\footnotetext{
* Corresponding author.

Email address: matteo.lattuada@allzool.bio.uni-giessen.de (M. Lattuada)
} 
2) assess spatial differences in individual pressure scores, i.e. the contribution of single anthropogenic pressures to the cumulative pressure scores and

3) investigate ecoregion-specific differences in pressure scores.

This spatially-explicit study is, to our best knowledge, the first attempt to quantify ecoregion-specific impacts of anthropogenic pressures in the Caspian Sea. It might thus provide important baseline data for subsequent management decisions and conservation strategies, for example in the frame of the Tehran Convention (Caspian Sea littoral countries, 2003).

\section{Methods}

\subsection{Study system}

The Caspian Sea is the largest enclosed water body in the world, with a surface area of about $370,000 \mathrm{~km}^{2}$. Located between Asia and Europe, it is bordered by five countries: Russia, Kazakhstan, Turkmenistan, Iran and Azerbaijan. It is limnologically divided into three parts (sub-basins) based on geophysical characteristics: the northern, middle and southern Caspian Sea (Rodionov, 1994).

The northern Caspian Sea has a maximum depth of $30 \mathrm{~m}$ and salinities below 10. Water-level, water current and salinity are strongly influenced by wind and river input, creating a highly dynamic environment. In contrast, the limnological conditions in the middle and southern Caspian Sea are more stable, with relatively constant salinities around 13. Water depths approach $800 \mathrm{~m}$ in the middle and exceed $1000 \mathrm{~m}$ in the southern Caspian Sea (Kosarev, 2005). Recently, the Caspian Sea has been divided into ten ecoregions (Fig. 1) based on ecologically relevant environmental variables (Fendereski et al., 2014).

\subsection{Cumulative environmental assessment analysis}

The cumulative environmental assessment (cea) analysis, used in the current study to evaluate the impact of anthropogenic pressures in the Caspian Sea, is based on the method of Halpern et al. (2008). Accordingly, a spatial grid of the study area was created with a grid cell resolution of 1 ArcMin, and cumulative pressure scores $\left(C_{t}\right.$, in the formula below) were calculated for each cell. As a specific pressure may have different impacts in different ecoregions, the impact of the pressures was weighted (Halpern et al., 2007; Halpern and Fujita, 2013). For doing so, the original equation for calculating cumulative pressure scores was modified as follows:

$\mathrm{C}_{\mathrm{t}}=\sum_{\mathrm{i}=1}^{\mathrm{n}} \mathrm{P}_{\mathrm{i}} * \mu_{\mathrm{i}}$

whereby $n$ is the number of the anthropogenic pressure layers, $P_{i}$ is the standardized intensity for each pressure layer and $\mu_{\mathrm{i}}$ is the weighting variable in each grid cell $i$. Note that $C_{t}$ was not calculated for areas with water depths of $>400 \mathrm{~m}$ due to the limited data available.

\subsection{Quantification of the contribution of individual anthropogenic pressures}

In the $\mathrm{C}_{\mathrm{t}}$ equation, $\mathrm{P}_{\mathrm{i}}$ represents the respective individual intensity of the key anthropogenic pressure proxies listed in the GIWA regional assessment (Stolberg et al., 2006, in Table 1). To construct specific proxies in space, data were taken from the literature and converted to raster layers (for details see Supplementary Data). For standardization purposes, some proxy layers were $\log [\mathrm{X}]$-transformed according to the distribution of their intensity values, and all were max-min linearly rescaled $\left(\left[x_{-} i-x_{-} \min \right] /\left[x_{-} \max -x_{-} \min \right]\right)$. The resulting values are unitless and range from 0 to 1 (Table 1 ).
The second element of the $C_{t}$ equation is the weighting variable $\mu_{\mathrm{i}}$. It was calculated by multiplying the stressor score of the respective anthropogenic pressure for the entire basin with the local stressor score. The former stressor score was estimated from literature data, following the method of Halpern et al. (2007), who developed a ranking system to evaluate the vulnerability of habitats to anthropogenic pressures. The vulnerability measures include scale, frequency and functional impact of the threats as well as resistance and recovery time of the ecosystem. It also includes the certainty of the evaluation to prioritize better known anthropogenic pressures. The local stressor score was taken from expert assessments (Stolberg et al., 2006). As the latter authors performed an expert evaluation to rank the anthropogenic pressures for each Caspian Sea littoral country, the results were transferred to the ecoregion level by applying a weighted average according to the shared surface between countries and ecoregion (see Supplementary Data).

\subsection{Ecoregion-specific differences in cumulative pressure scores}

For inferring ecoregion-specific (and thus spatially- and bathymetrically-specific) differences in cumulative pressure scores, a Principal Component Analysis (PCA) was conducted. The PCA was run using the function princomp in the base package stats for the statistical environment R (R Core Team, 2016). Additionally, a similarity matrix based on the Euclidean distance between the contributions of individual pressure effects was calculated for the ecoregions. This similarity matrix was then used to cluster the ecoregions with the Partitioning Around Medoids (PAM) method, a more robust version of K-means (Reynolds et al., 1992). These analyses were done with the functions daisy and pam of the R package cluster (Maechler et al., 2016). Visual plots were created with the package ggplot2 (Wickham, 2009) and maps were generated in ArcGIS 10.5 (ESRI).

\section{Results}

\subsection{Cumulative and individual pressure scores in the Caspian Sea}

Cumulative pressure scores in the Caspian Sea ranged from 0.23 to 2.35 (theoretical values 0 to 4 ; Fig. 2a). The highest scores were estimated for the Baku area and in the west of the Volga Delta. Lowest scores were detected in the deeper parts (below $120 \mathrm{~m}$ ) of the middle Caspian Sea sub-basin (Fig. 2a).

The three northwestern ecoregions of the Caspian Sea showed the highest average cumulative pressure scores (NCB- $T=1.46$, NCB-RO $=1.31$, NCB-WS $=1.30$ ) of all Caspian Sea ecoregions, with the most relevant individual pressure being poaching (Fig. $2 b$, Table 2).

Lowest average cumulative pressure scores were calculated for the open water ecoregions MCB-OS and SCB-OS with scores of 0.47 and 0.69 , respectively. For the latter ecoregions, the strongest individual pressure was chemical pollution (Table 2).

Overall, three anthropogenic pressures (invasive species, chemical pollution and poaching) were the highest individual contributors to the cumulative pressure scores (Table 2, for a full list of all anthropogenic pressure contributions see Supplementary Data). Each of them was responsible for at least $10 \%$ of the scores in more than half of the Caspian Sea grid cells (Fig. 3).

\subsection{Ecoregion-specific differences in individual pressure scores}

The PCA, which was conducted to infer ecoregion-specific differences in individual pressures, showed three clusters (Fig. 4). The two dominant factors are poaching and chemical pollution (78\% of the summative variance; $\sigma^{2}=0.11$; Fig. 4). They have loadings on the first PC of -0.757 and 0.617 , respectively. 


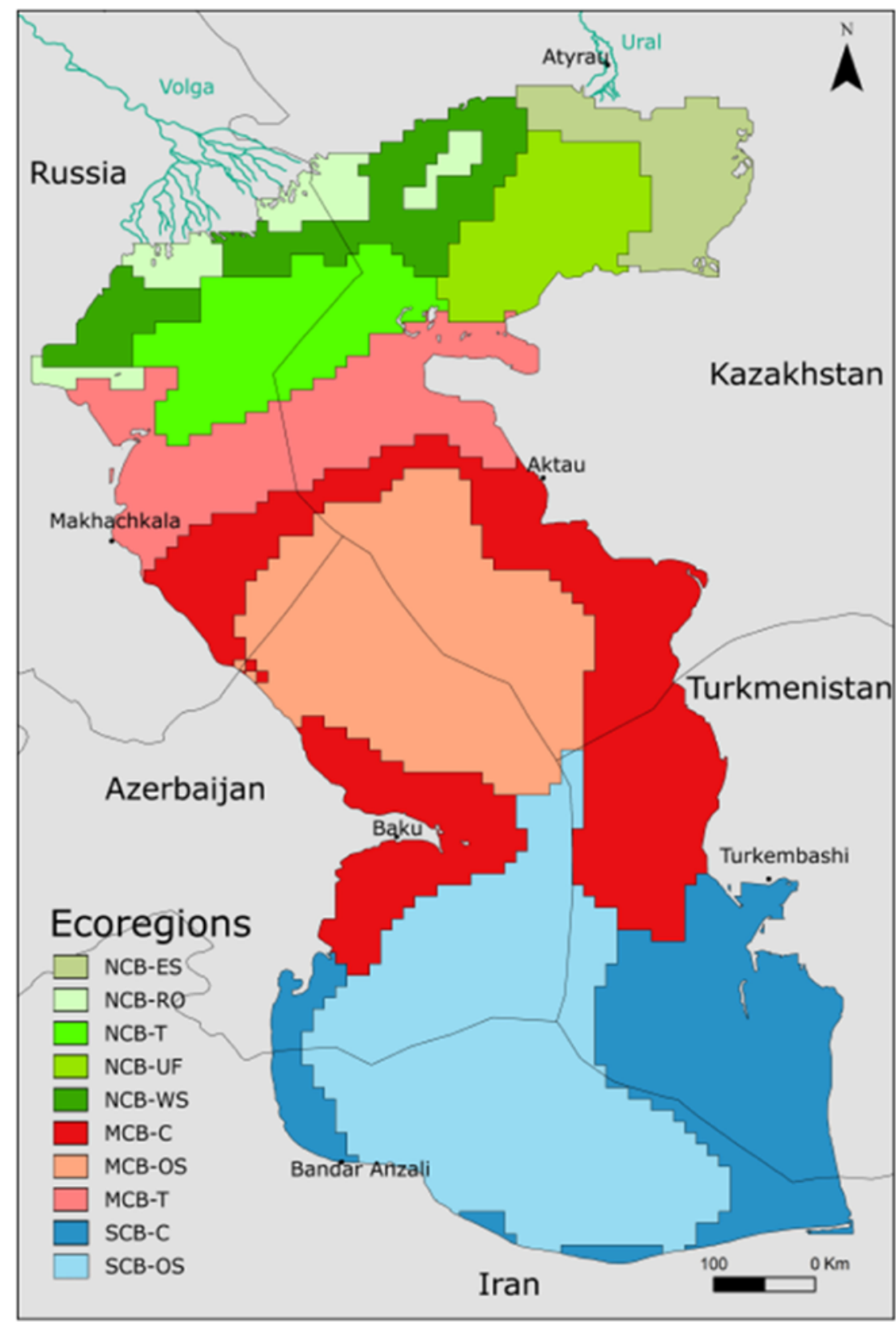

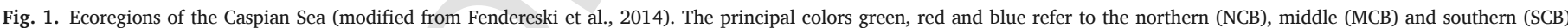

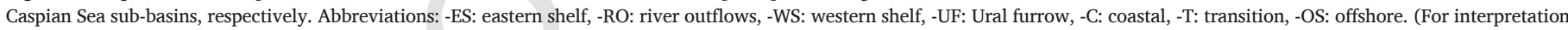
of the references to color in this figure legend, the reader is referred to the web version of this article.)

The dissimilarity of individual pressure contributions across paired ecoregions, measured as Euclidean distance, is visualized in Fig. 5. The two offshore ecoregions, MCB-OS and SCB-OS, showed the highest difference to the northern Caspian ecoregions (for detailed values see Supplementary Data).

The PAM analysis of ecoregions yielded two clusters (Fig. 2 in Supplementary Data). The first contained the five northern ecoregions and MCB-T (maximum and average Euclidean distance between elements 0.24 and 0.11 , respectively), the second included MCB-C, MCB-OS and SCB (maximum and average Euclidean distances between elements 0.35 and 0.19 , respectively; see Supplementary Data).

\section{Discussion}

Our results show that cumulative pressure scores are not equally distributed across the study area. Highest scores were found in Azerbaijani waters, near major oil fields and near the entrance of the Volga Delta. In contrast, offshore areas, in particular with water depths $>120 \mathrm{~m}$, had comparably low scores. We also found that both cumulative and individual pressure scores vary greatly among ecoregions. In the following sections, we discuss i) the socio-political and economic factors causing these spatial differences in anthropogenic pressure and ii) ecoregion-specific differences in anthropogenic pressure contributions. 
Table 1

Major anthropogenic activities/pressures in the Caspian Sea (following Stolberg et al., 2006) and respective proxies used for the CEA analysis. Note that anthropogenic pressure proxies are not mutually exclusive. For methodological details see Supplementary Data.

\begin{tabular}{|c|c|c|}
\hline $\begin{array}{l}\text { Anthropogenic } \\
\text { pressure/activity }\end{array}$ & Proxy used in this study & Reference \\
\hline $\begin{array}{l}\text { Unsustainable } \\
\text { fishing }\end{array}$ & Rate of annual fish catch & FAO (2018) \\
\hline Chemical pollution & $\begin{array}{l}\text { Concentration of chemical } \\
\text { pollutants in sediment }\end{array}$ & $\begin{array}{l}\text { de Mora et al. (2004), } \\
\text { Tolosa et al. (2004) }\end{array}$ \\
\hline $\begin{array}{l}\text { Streamflow } \\
\text { regulation }\end{array}$ & Sturgeon abundance & $\begin{array}{l}\text { Lagutov (2008), } \\
\text { Khodoresvkaya (2009) }\end{array}$ \\
\hline Invasive species & $\begin{array}{l}\text { Occurrence of invasive } \\
\text { species }\end{array}$ & Karpinsky (2002) \\
\hline $\begin{array}{l}\text { Oil industry } \\
\text { disturbances }\end{array}$ & $\begin{array}{l}\text { Oil infrastructure and } \\
\text { transportation }\end{array}$ & $\begin{array}{l}\text { Anonymous (2012), AIS } \\
\text { Marine Traffic (2016) }\end{array}$ \\
\hline $\begin{array}{l}\text { Coastal } \\
\text { development }\end{array}$ & $\begin{array}{l}\text { Human population densities } \\
\text { along coastline }\end{array}$ & CIESIN (2016) \\
\hline $\begin{array}{l}\text { Agriculture by- } \\
\text { product } \\
\text { discharge }\end{array}$ & $\begin{array}{l}\text { Total nitrogen content in } \\
\text { river catchment }\end{array}$ & $\begin{array}{l}\text { Potter et al. (2011), Lehner } \\
\text { and Grill (2013) }\end{array}$ \\
\hline Eutrophication & Chlorophyll $a$ content & $\begin{array}{l}\text { NASA Ocean Color Data } \\
(2017)\end{array}$ \\
\hline Poaching & $\begin{array}{l}\text { Areas with poaching } \\
\text { activities }\end{array}$ & $\begin{array}{l}\text { Dmitrieva et al. (2013), } \\
\text { Strukova et al. (2016) }\end{array}$ \\
\hline
\end{tabular}

\subsection{Contribution of individual pressures to the cumulative pressure scores}

The anthropogenic pressures with the highest individual contributions are poaching, chemical pollution and invasive species. The former pressure has a higher impact in the northern Caspian Sea sub-basin; the latter two in the middle and southern sub-basins (Fig. 3). These findings indicate that similar cumulative pressure scores in different parts of the Caspian Sea (e.g., near the entrance to the Volga Delta and around Baku; Fig. 2a) may be caused by locally or regionally different individual pressures. The spatial differences are largely driven by socio-political and economic factors, mostly related to the collapse of the industrial sector of the former Soviet Union (Kosarev and Yablonskaya, 1994; Dumont, 1995; Zonn, 2005). For example, registered sturgeon catches peaked in the late 1980 's. A few years later, the fishing fleet was largely dismantled and anglers started to harvest sturgeons without formal regulation (Khodorevskaya et al., 2014; Mammadov et al., 2016; Strukova et al., 2016). Our results indicate that poaching is still a major concern (Fig. 3 ) and that the effectiveness of the different national anti-poaching approaches may vary (Ermolin and Svolkinas, 2016).

The spatial pattern of chemical pollution is also linked to the socio-economic development of oil exploration in the Caspian Sea (Kosarev and Yablonskaya, 1994). In 1950, the first oil wells were drilled off the coast of Azerbaijan, while land-based oil production already started a century earlier (Zhiltsov et al., 2016). Given the poor environmental standards at that time and the subsequent abandonment of wells, a persistent leaking of oil compounds and heavy metals into the water has been evident (Bickham et al., 1998; de Mora et al., 2004). Pollutant concentrations were at alarming levels in the 1980's and 1990's, when heavy metal residuals from mining activities increased chemical pollution (de Mora et al., 2004). Recently, hazardous chemicals are decreasing along the coasts of the Caspian Sea (Nemirovskaya, 2016). However, pollutants are increasingly accumulated in the deepest parts of the basin due to water cycles (Tolosa et al., 2004; Korshenko and Gul, 2005; Nemirovskaya, 2016). a)

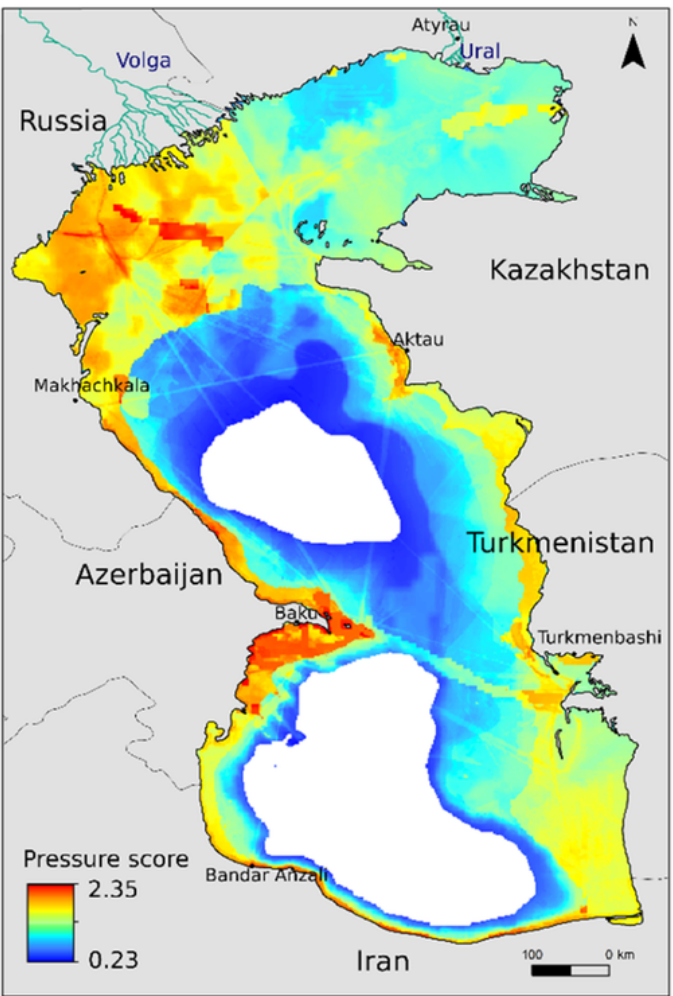

b)

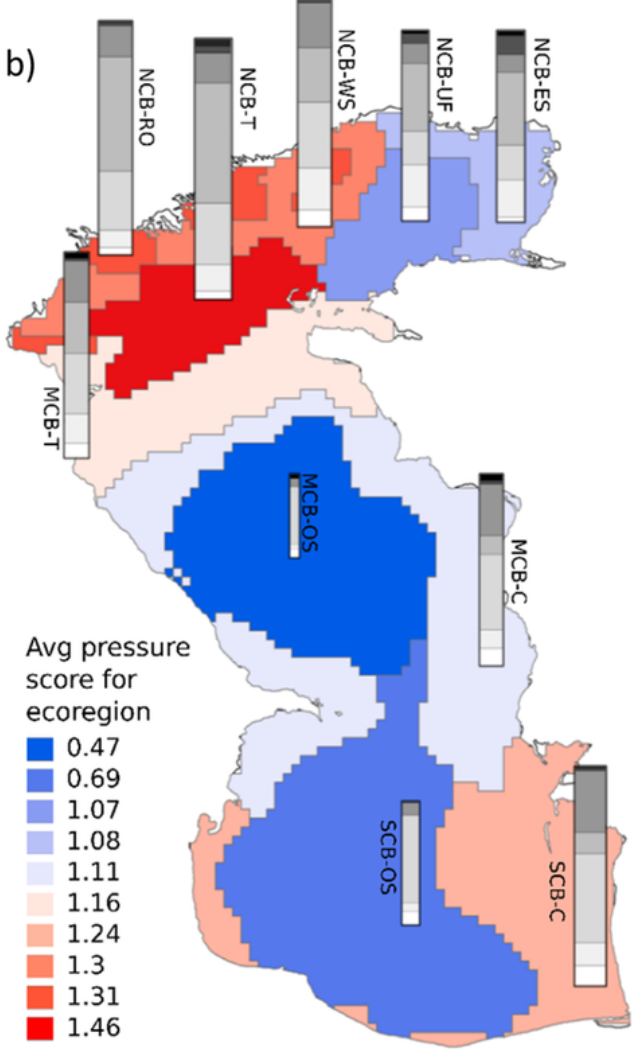

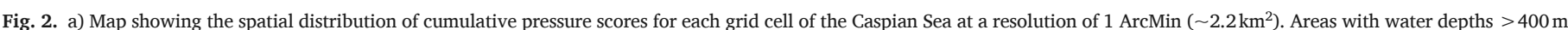

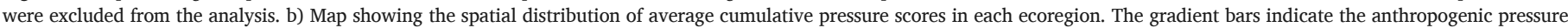
contribution for each ecoregion. For detailed values see Table 2. 
Table 2

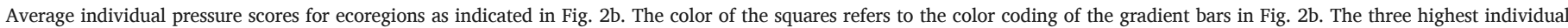
pressure scores for each ecoregion are indicated in bold.

\begin{tabular}{|c|c|c|c|c|c|c|c|c|c|}
\hline Ecoregion & Eutrophication & $\begin{array}{l}\text { Agriculture by-product } \\
\text { discharge }\end{array}$ & $\begin{array}{l}\text { Unsustainable } \\
\text { fishing }\end{array}$ & $\begin{array}{l}\text { Coastal } \\
\text { development }\end{array}$ & $\begin{array}{l}\text { Invasive } \\
\text { species }\end{array}$ & Poaching & $\begin{array}{l}\text { Chemical } \\
\text { pollution }\end{array}$ & $\begin{array}{l}\text { Streamflow } \\
\text { regulation }\end{array}$ & $\begin{array}{l}\text { Oil industry } \\
\text { disturbances }\end{array}$ \\
\hline MCB-C & 0.04 & 0.01 & 0.01 & 0 & 0.27 & 0.1 & 0.4 & 0.08 & 0.09 \\
\hline MCB-OS & 0.05 & 0 & 0 & 0 & 0.09 & 0.01 & 0.72 & 0.03 & 0.1 \\
\hline MCB-T & 0.03 & 0.01 & 0.01 & 0 & 0.2 & 0.25 & 0.29 & 0.14 & 0.07 \\
\hline NCB-ES & 0 & 0.03 & 0 & 0 & 0.13 & 0.51 & 0.25 & 0.05 & 0.03 \\
\hline NCB-RO & 0.01 & 0.01 & 0 & 0 & 0.11 & 0.45 & 0.2 & 0.19 & 0.01 \\
\hline NCB-T & 0.03 & 0 & 0 & 0 & 0.12 & 0.38 & 0.21 & 0.18 & 0.08 \\
\hline NCB-UF & 0 & 0 & 0 & 0 & 0.14 & 0.51 & 0.26 & 0.06 & 0.03 \\
\hline NCB-WS & 0.01 & 0.01 & 0 & 0 & 0.11 & 0.45 & 0.21 & 0.19 & 0.02 \\
\hline SCB-C & 0.02 & 0.04 & 0 & 0.02 & 0.32 & 0.12 & 0.4 & 0.03 & 0.04 \\
\hline SCB-OS & 0.05 & 0.02 & 0 & 0 & 0.14 & 0.01 & 0.68 & 0 & 0.1 \\
\hline
\end{tabular}

Invasive species

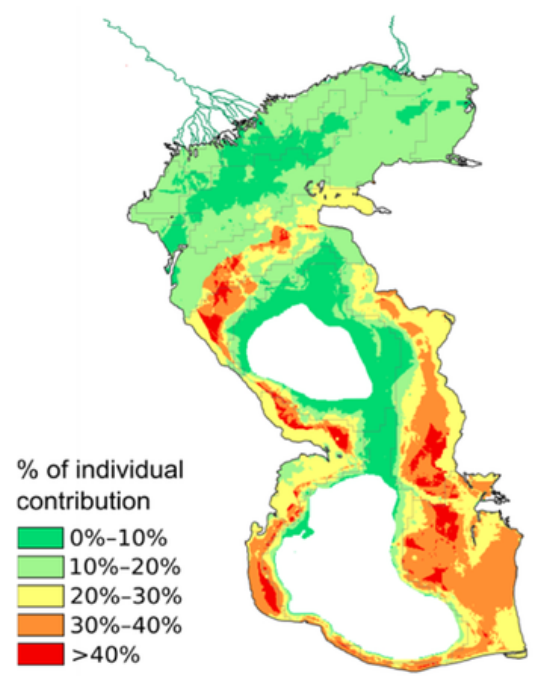

Chemical pollution

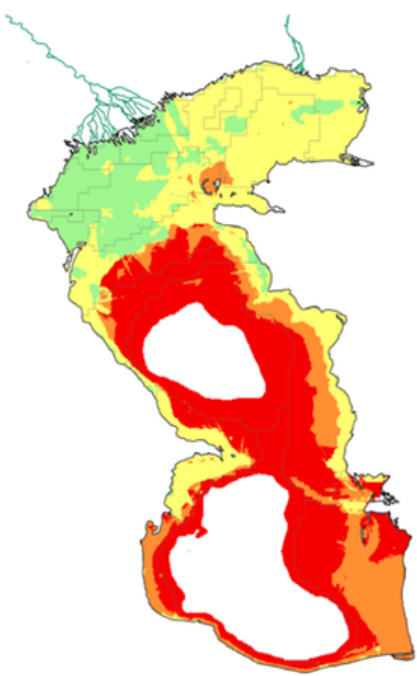

Poaching

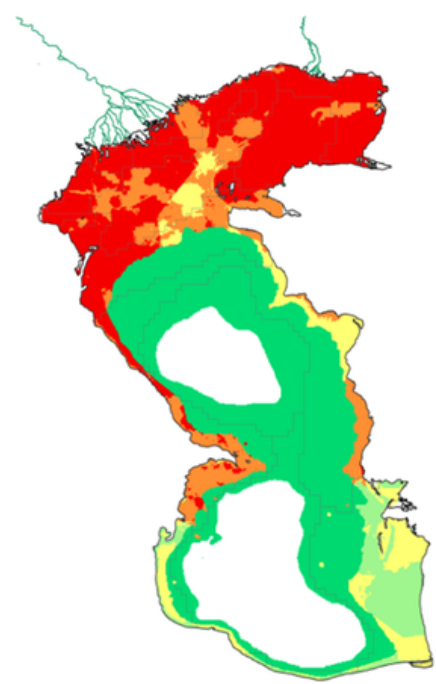

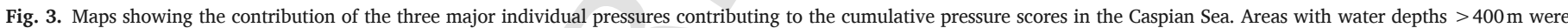
excluded from the analysis.

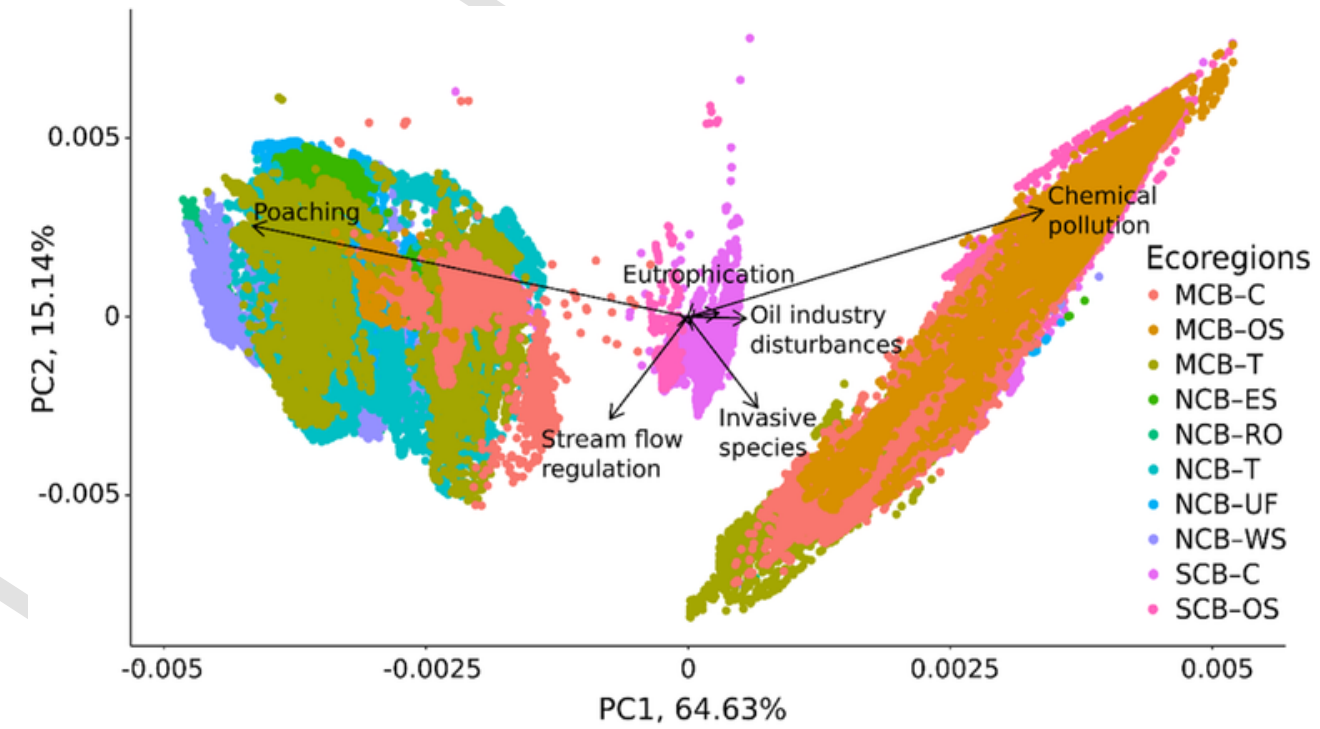

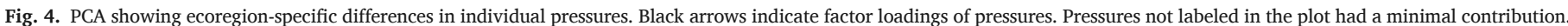
For abbreviations of ecoregions see Fig. 1. 


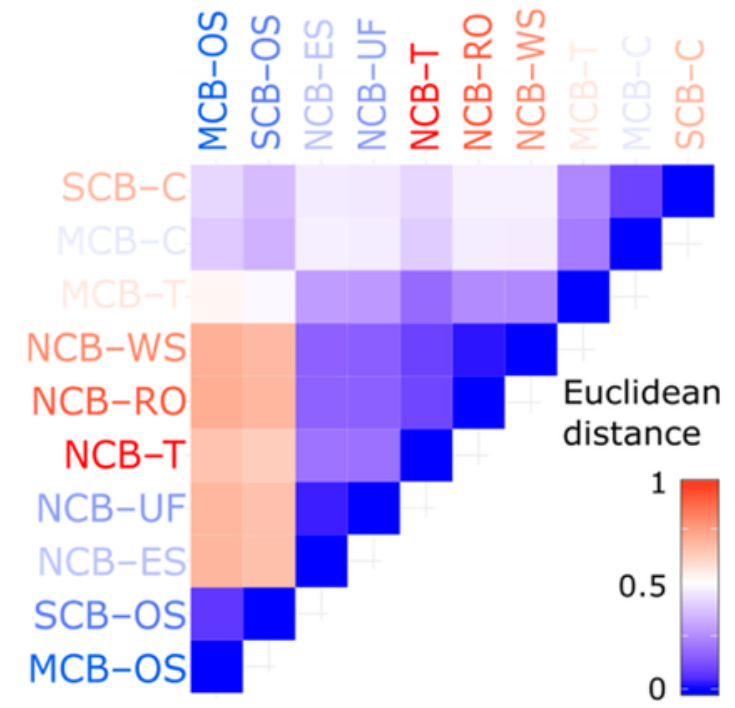

Fig. 5. Similarity matrix based on Euclidean distances between ecoregions. Colors of ecoregion labels indicate average cumulative pressure scores according to Fig. 2b. For abbreviations see Fig. 1.

The continued introduction of invasive species, too, is directly linked to the economic development of the region. This concerns both the intended and unintended introduction. In the early 20th century, several invertebrate species, such as the annelid worm Nereis diversicolor and the bivalve Abra segmentum, were intentionally introduced in the Caspian Sea to increase feed biomass for sturgeon stock (Shiganova, 2010). Unintentional introductions were largely fostered by the construction of the Volga-Don Canal in 1952. It connects the Caspian Sea with the Black Sea and thus with the world's ocean (Shiganova, 2010). This, in turn, promotes the active and passive colonization of the Caspian Sea by invasive species. An example is Mnemiopsis leidiy, a comb jellyfish that originated in the Atlantic Ocean and reached the Caspian Sea in 1998 (Shiganova, 2010). This species caused the sharp decline of fish catches in Iran, as it competes with commercially used fish for food resources and preys on their eggs (Roohi et al., 2010, 2016; Pourang et al., 2016). The highest impact of invasive species can be seen in the middle and southern Caspian Sea, which are ecologically more similar to the native marine ecosystems of many introduced species (Shiganova, 2010).

Our results also show that cumulative pressure scores are an important mean for identifying spatial differences in overall human impacts on Caspian Sea ecoregions (Fig. 2a). However, different combinations of individual stressors (Fig. 3) may result in similar cumulative pressure scores. Therefore, the utilization of individual pressure scores might be more straightforward for implementing targeted (i.e., speciesand area-specific) conservation and remediation practices.

\subsection{Ecoregion-specific differences in anthropogenic pressure contribution}

The ecoregions most affected by anthropogenic pressures are those in the continental shelf of the northwestern (NCB-T, NCB-RO, NCB-WS) and southern Caspian Sea (SCB-C). Ecoregions least affected are those in coastal areas of the northeastern Caspian Sea (NCB-UF, NCB-ES) as well as in the analyzed deepest parts of the basin (MCB-OS, SCB-OS) (Figs. 2b, 5). Moreover, our PCA analysis shows ecoregion-specific differences in the spatial distribution of individual anthropogenic pressures. Besides the main pressures discussed under 4.1. (i.e. poaching, chemical pollution and invasive species), other factors such as eutrophication, stream flow regulation and oil industry disturbance also play a role, although the effects remain rather localized (Fig. 4 and Table 2). These patterns indicate strong bathymetrical and latitudinal diver- gences of cumulative and individual anthropogenic pressures among ecoregions. However, as shown by the similarity matrix in Fig. 5, similar ecoregions may also be affected by similar individual pressures.

The northern sub-basin, which lacks deep-water habitats and is nutrient-rich, favors the biomass growth of the main prey of young sturgeons (Guseinov, 2005; Malinovskaya and Zinchenko, 2010, 2011). As a consequence, the respective ecoregions are subject to a high impact from poaching (Dmitrieva et al., 2013). In contrast, they face relatively low impact from chemical pollution due to a geochemical barrier at the transition between fresh and brackish water, and the rich vegetation of the Volga Delta (Nemirovskaya, 2016). Invasive marine species also remain scarce in these ecoregions likely due to low salinities (Shiganova, 2010).

The ecoregions of the middle and southern Caspian Sea also show similar distributions of cumulative and individual anthropogenic pressures, with coastal ecoregions being more affected than offshore ones. Here, main individual pressures are invasive species (see Section 4.1.) and poaching. The latter may be explained by the fact that sturgeons migrate along the coastlines of the Caspian Sea, feeding on the rich benthos (Karpinsky, 2010).

Deep-water ecoregions of the middle and southern Caspian Sea are less affected by invasive species and poaching, but suffer from chemical pollution. This is due to the fact that these parts function as a sink for fine particles, as strong wind in the northern Caspian Sea move water and sediments southwards (Tolosa et al., 2004). In addition, deep-water ecoregions represent natural oil seeps (Nemirovskaya, 2016). Some of the respective compounds might be biologically magnified along the food chain, causing physiological impairments (Bickham et al., 1998; Moore et al., 2003; Wilson et al., 2014). Thus, chemical pollution may be of particular concern for endemic species in the deeper parts of the Caspian Sea (Parr et al., 2007; Tait et al., 2016) and could, for example, explain the strong decline of mollusks species in the profundal zone (Wesselingh et al., 2019).

Our ecoregion-specific analyses of anthropogenic pressure contributions show clear differences in cumulative and individual pressures among dissimilar ecoregions. As the respective ecoregions also harbor different native and endemic species, we may experience further shifts in community-assemblages in the future. This might, in particular, concern endemic species both in shallow and deeper waters, as well as native (including commercially-important) species in coastal ecoregions. These findings, in turn, substantiate the need for ecoregion-specific conservation efforts.

\section{Conclusions}

Cumulative pressure scores in the Caspian Sea are unevenly distributed, with coastal areas, particularly near major oil fields and the Volga Delta, showing higher values than deep-water areas. As the ten ecoregions in the Caspian Sea are, in part, defined by latitude and water depth, cumulative pressure scores also vary among ecoregions. However, analyses of individual anthropogenic pressures provide a more differentiated picture. Accordingly, the most important pressures are invasive species, chemical pollution and poaching. Invasive species are of particularly concern in the shelf areas of the middle and southern Caspian Sea sub-basins, i.e. in regions where the ecological conditions may allow introduced marine species to survive. In the shelf areas of the northern Caspian Sea sub-basin, poaching is the most severe anthropogenic pressure, hinting to region-specific differences in poaching intensities and regional problems in the implementation of anti-poaching strategies. Finally, the deep-water areas of the Caspian Sea are particularly affected by chemical pollution as they may serve as sinks for pollutants. This uneven distribution of cumulative and individual pressure scores also concerns the individual ecoregions of the Caspian Sea, and their native and endemic species. This finding is of particular inter- 
est for future conservation strategies as species in dissimilar ecoregions might be affected by different anthropogenic pressures. We also show that cumulative pressure scores are an important mean for identifying spatial differences in overall human impacts. However, for implementing targeted conservation and remediation practices, a consideration of the underlying individual pressure scores might be more expedient.

This paper provided the first ecoregion-specific CEA analysis for the Caspian Sea. As such, our results might serve as a base line for future impact studies and for the prioritization of remediation plans, for example in the context of the Tehran Convention.

\section{Declarations of interest}

None.

\section{Acknowledgments}

This research was supported by the project PRIDE (Pontocaspian RIse and DEmise), which has received funding from the European Union's Horizon 2020 research and innovation program under the Marie Sklodowska-Curie grant agreement No 642973. Many thanks go to Elena Jovanovska, Torsten Hauffe and Arthur F. Sands for the helpful discussions.

\section{Appendix A. Supplementary data}

Supplementary data to this article can be found online at https:// doi.org/10.1016/j.marpolbul.2019.03.046.

\section{References}

Agah, H., Leermakers, M., Elskens, M., Fatemi, S.M.R., Baeyens, W., 2007. Total mercury and methyl mercury concentrations in fish from the Persian Gulf and the Caspian Sea. Water Air Soil Pollut. 181, 95-105. https://doi.org/10.1007/s11270-006-9281-0.

Aliyeva, G., Halsall, C., Alasgarova, K., Avazova, M., Ibrahimov, Y., Aghayeva, R., 2013. The legacy of persistent organic pollutants in Azerbaijan: an assessment of past use and current contamination. Environ. Sci. Pollut. Res. 20, 1993-2008. https://doi.org/ 10.1007/s11356-012-1076-9.

Bastami, K.D., Bagheri, H., Kheirabadi, V., Zaferani, G.G., Teymori, M.B., Hamzehpoor, A., Soltani, F., Haghparast, S., Harami, S.R.M., Ghorghani, N.F., Ganji, S., 2014. Distribution and ecological risk assessment of heavy metals in surface sediments along southeast coast of the Caspian Sea. Mar. Pollut. Bull. 81, 262-267. https://doi.org/10. 1016/j.marpolbul.2014.01.029.

Bickham, J.W., Rowe, G.T., Palatnikov, G., Mekhtiev, n A., Mekhtiev, M., Kasimov, R.Y., Hauschultz, D.W., Wickliffe, J.K., Rogers, W.J., 1998. Acute and genotoxic effects of Baku Harbor sediment on Russian sturgeon, Acipenser guildensteidti. Bull. Environ. Contam. Toxicol. 61, 512-518.

Caspian Sea littoral countries, 2003. Framework Convention for the Protection of the Marine Environment of the Caspian Sea. UNEP.

Dmitrieva, L., Kondakov, A.A., Oleynikov, E., Kydyrmanov, A., Karamendin, K., Kasimbekov, Y., Baimukanov, M., Wilson, S., Goodman, S.J., 2013. Assessment of Caspian seal by-catch in an illegal fishery using an interview-based approach. PLoS One 8, e67074https://doi.org/10.1371/journal.pone.0067074.

Dumont, H., 1995. Ecocide in the Caspian Sea. Nature 377, 673-674. https://doi.org/10. $1038 / 377673 \mathrm{a0}$

Ermolin, I., Svolkinas, L., 2016. Who owns sturgeon in the Caspian? New theoretical model of social responses towards state conservation policy. Biodivers. Conserv. 25, 2929-2945. https://doi.org/10.1007/s10531-016-1211-x.

Fendereski, F., Vogt, M., Payne, M.R., Lachkar, Z., Gruber, N., Salmanmahiny, A., Hosseini, S.A., 2014. Biogeographic classification of the Caspian Sea. Biogeosciences 11, 6451-6470. https://doi.org/10.5194/bg-11-6451-2014.

Guseinov, M.K., 2005. Zoobenthic communities of the Dagestan region of the Caspian Sea. Russ. J. Mar. Biol. 31, 7-13.

Halpern, B.S., Fujita, R., 2013. Assumptions, challenges, and future directions in cumulative impact analysis. Ecosphere 4, 1-11. https://doi.org/10.1890/ES13-00181.1.

Halpern, B.S., Selkoe, K.A., Micheli, F., Kappel, C.V., 2007. Evaluating and ranking the vulnerability of global marine ecosystems to anthropogenic threats. Conserv. Biol. 21, 1301-1315. https://doi.org/10.1111/j.1523-1739.2007.00752.x.

Karpinsky, M.G., 2005. Biodiversity. In: The Caspian Sea Environment, Water Pollution. Springer, pp. 191-209.

Karpinsky, M.G., 2010. Review: the Caspian Sea benthos: unique fauna and community formed under strong grazing pressure. Mar. Pollut. Bull. 61, 156-161. https://doi.org/ 10.1016/j.marpolbul.2010.02.009.

Khodorevskaya, R., Kim, Y., Shahifar, R., Mammadov, E., Katunin, D., Morozov, B., Akhundov, M., Muradov, O., Velikova, V., 2014. State and dynamics of the bioresources in the Caspian Sea. In: The Handbook of Environmental Chemistry. Springer Berlin Heidelberg, pp. 1-84. https://doi.org/10.1007/698_2014_287.
Korshenko, A., Gul, A.G., 2005. Pollution of the Caspian Sea. In: The Caspian Sea Environment, Water Pollution. Springer, pp. 109-142.

Kosarev, A.N., 2005. Physico-geographical conditions of the Caspian Sea. In: The Caspian Sea Environment, Water Pollution. Springer, pp. 5-32.

Kosarev, A.N., Yablonskaya, E.A., 1994. The Caspian Sea. SPB Academic Publishing, The Hague.

Latypov, Y.Y., 2015. The bivalve Mollusc Abra ovata: role in succession of soft bottom communities on newly flooded area of the Caspian Sea. Am. J. Clim. Chang. 04, 239. https://doi.org/10.4236/ajcc.2015.43019.

Maechler, M., Rousseeuw, P., Struyf, A., Hubert, M., Hornik, K., 2016. Cluster: Cluster Analysis Basics and Extensions. R Package Version 2.0.5.

Malinovskaja, L.V., Filippov, A.A., Osadchikh, V.F., Aladin, N.V., 1998. Benthic macroinvertebrates of the northern Caspian Sea during recent rises in water-level. Int. J. Salt Lake Res. 7, 211-233.

Malinovskaya, L.V., Zinchenko, T.D., 2010. Mytilaster lineatus (Gmelin): long-term dynamics, distribution of invasive mollusk in the northern Caspian Sea. Russ. J. Biol Invasions 1, 288-295. https://doi.org/10.1134/S2075111710040065.

Malinovskaya, L.V., Zinchenko, T.D., 2011. Long-term dynamics of the biomass of the in troduced species Hediste diversicolor Müller and Abra ovata (Philippi) in the North Caspian Sea. Russ. J. Biol. Invasions 2, 20-28. https://doi.org/10.1134/ S2075111711010048.

Mammadov, E., Timirkhanov, S., Shiganova, T., Katunin, D., Abdoli, A., Shahifar, R., Kim, Y., Khodorevsakaya, R., Annachariyeva, J., Velikova, V., 2016. Management of Caspian biodiversity protection and conservation. In: SpringerLink, the Handbook of Environmental Chemistry. Springer, Berlin, Heidelberg, pp. 1-34. https://doi.org/10. 1007/698_2016_463.

Mashroofeh, A., Bakhtiari, A.R., Pourkazemi, M., 2015. Distribution and composition pattern of polycyclic aromatic hydrocarbons in different tissues of sturgeons collected from Iranian coastline of the Caspian Sea. Chemosphere 120, 575-583. https://doi. org/10.1016/j.chemosphere.2014.09.071.

Moore, M.J., Mitrofanov, I.V., Valentini, S.S., Volkov, V.V., Kurbskiy, A.V., Zhimbey, E.N., Eglinton, L.B., Stegeman, J.J., 2003. Cytochrome P4501A expression, chemical contaminants and histopathology in roach, goby and sturgeon and chemical contaminants in sediments from the Caspian Sea, Lake Balkhash and the Ily River Delta, Kazakhstan. Mar. Pollut. Bull. 46, 107-119.

de Mora, S., Sheikholeslami, M.R., Wyse, E., Azemard, S., Cassi, R., 2004. An assessment of metal contamination in coastal sediments of the Caspian Sea. Mar. Pollut. Bull. 48, 61-77. https://doi.org/10.1016/S0025-326X(03)00285-6.

Nasrabadi, T., Nabi Bidhendi, G., Karbassi, A., Grathwohl, P., Mehrdadi, N., 2011. Impact of major organophosphate pesticides used in agriculture to surface water and sediment quality (southern Caspian Sea basin, Haraz River). Environ. Earth Sci. 63, 873-883. https://doi.org/10.1007/s12665-010-0757-2.

Nemirovskaya, I.A., 2016. Hydrocarbons in the modern sediments of the Caspian Sea. Water Resour. 43, 111-120. https://doi.org/10.1134/S009780781506007X.

Parr, T.D., Tait, R.D., Maxon, C.L., Newton, F.C., Hardin, J.L., 2007. A descriptive account of benthic macrofauna and sediment from an area of planned petroleum exploration in the southern Caspian Sea. Estuar. Coast. Shelf Sci. 71, 170-180. https://doi.org/10. 1016/j.ecss.2006.07.018.

Poorbagher, H., Hosseini, S.V., Hosseini, S.M., Aflaki, F., Regenstein, J.M., 2017. Metal accumulation in Caspian sturgeons with different feeding niches, condition factor, body size and age. Microchem. J. 132, 43-48. https://doi.org/10.1016/j.microc.2017.01. 003.

Pourang, N., Eslami, F., Saravi, H.N., Fazli, H., 2016. Strong biopollution in the south ern Caspian Sea: the comb jelly Mnemiopsis leidyi case study. Biol. Invasions 18 2403-2414. https://doi.org/10.1007/s10530-016-1171-9.

R Core Team, 2016. R: A Language and Environment for Statistical Computing. R Foundation for Statistical Computing, Vienna, Austria, URL https://www.R-project.org/.

Reynolds, A., Richards, G., de la Iglesia, B., Rayward-Smith, V., 1992. Clustering rules: a comparison of partitioning and hierarchical clustering algorithms. J. Math. Model. Algorithm. 475-504. https://doi.org/10.1007/s10852-005-9022-1.

Rodionov, S.N., 1994. Global and Regional Climate Interaction: The Caspian Sea Experience. Springer.

Roohi, A., Kideys, A.E., Sajjadi, A., Hashemian, A., Pourgholam, R., Fazli, H., Khanari, A.G., Eker-Develi, E., 2010. Changes in biodiversity of phytoplankton, zooplankton, fishes and macrobenthos in the Southern Caspian Sea after the invasion of the ctenophore Mnemiopsis Leidyi. Biol. Invasions 12, 2343-2361. https://doi.org/10. 1007/s10530-009-9648-4.

Roohi, A., Rowshantabari, M., Jolodar, M.N., Sajjadi, S.A., 2016. The Effect of the Ctenophore Mnemiopsis leidyi (Ctenophora: Lobata) on the Population Density and Species Composition of Mesoplankton in Inshore Waters of the Caspian Sea.

Shiganova, T., 2010. Biotic homogenization of inland seas of the Ponto-Caspian. Annu. Rev. Ecol. Evol. Syst. 41, 103-125. https://doi.org/10.1146/annurev.ecolsys.110308. 120148.

Stolberg, F.V., Borysova, O., Mitrofanov, I., Barannik, V., Eghtesadi, P., 2006. Global International Water Assessment 23. University of Kalmar on behalf of United Nations Environment Programme, Caspian Sea.

Strukova, E., Guchgeldiyev, O., Evans, A., Katunin, D., Khodorevskaya, R., Kim, Y., Akhundov, M., Mammadli, T., Shahivar, R., Muradov, O., Mammadov, E., Velikova, V., 2016. Exploitation of the Caspian Sea Bioresources (with Focus on Economics of Bioresources Utilization). 1-44. https://doi.org/10.1007/698_2015_452.

Tait, R.D., Maxon, C.L., Parr, T.D., Newton, F.C., 2016. Benthos response following petroleum exploration in the southern Caspian Sea: relating effects of nonaqueous drilling fluid, water depth, and dissolved oxygen. Mar. Pollut. Bull. 110, 520-527. https://doi. org/10.1016/j.marpolbul.2016.02.079.

Tolosa, I., de Mora, S., Sheikholeslami, M.R., Villeneuve, J.-P., Bartocci, J., Cattini, C., 2004. Aliphatic and aromatic hydrocarbons in coastal Caspian Sea sediments. Mar. Pollut. Bull. 48, 44-60. https://doi.org/10.1016/S0025-326X(03)00255-8.

Varnosfaderany, M.N., Bakhtiari, A.R., Gu, Z., Chu, G., 2015. Distribution and characteristic of PAHs in sediments from the southwest Caspian Sea, Guilan Province, Iran. Water Sci. Technol. 71, 1587. https://doi.org/10.2166/wst.2015.091. 
Wesselingh, F., Neubauer, T.A., Anistratenko, V., Vinarski, M.V., Yanina, T., ter Poorten, J.J., Kijashko, P., Albrecht, C., Anistratenko, O., D'Hont, A., Frolov, P., Martínez Gándara, A., Gittenberger, A., Gogaladze, A., Karpinsky, M., Lattuada, M., Popa, L., Sands, A., van de Velde, S., Vandendorpe, J., Wilke, T., 2019. Mollusc species from the Pontocaspian region - an expert opinion list. ZooKeys 827, 31-124. https://doi. org $/ 10.3897 /$ zookeys.827.31365.

Wickham, H., 2009. ggplot2: Elegant Graphics for Data Analysis. Springer-Verlag, New York.

Wilson, S.C., Eybatov, T.M., Amano, M., Jepson, P.D., Goodman, S.J., 2014. The role of canine distemper virus and persistent organic pollutants in mortality patterns of Caspian seals (Pusa caspica). PLoS One 9, e99265https://doi.org/10.1371/journal. pone.0099265.

Yancheshmeh, R.A., Bakhtiari, A.R., Mortazavi, S., Savabieasfahani, M., 2014. Sediment PAH: contrasting levels in the Caspian Sea and Anzali wetland. Mar. Pollut. Bull. 84, 391-400. https://doi.org/10.1016/j.marpolbul.2014.05.001.
Yanina, T.A., 2014. The Ponto-Caspian region: environmental consequences of climate change during the Late Pleistocene. Quat. Int. 345, 88-99. https://doi.org/10.1016/j. quaint.2014.01.045.

Zarbaliyeva, T.S., Akhundov, M.M., Kasimov, A.M., Nadirov, S.N., Hyseynova, G.G., 2016. The influence of invasive species on the Caspian Sea aboriginal fauna in the coastal waters of Azerbaijan. Russ. J. Biol. Invasions 7, 227-236. https://doi.org/10.1134/ S2075111716030139.

Zenkevitch, L., 1963. Biology of the Seas of the USSR. GEORGE ALLEN \& UNWIN LTD RUSKIN HOUSE MUSEUM STREET, London.

Zhiltsov, S.S., Zonn, I.S., Kostianoy, A.G., 2016. Oil and gas pipelines in the black-Caspian seas region. In: The Handbook of Environmental Chemistry. Springer International Publishing, Cham.

Zonn, I.S., 2005. Environmental issues of the Caspian. In: The Caspian Sea Environment, Water Pollution. Springer, pp. 223-242. 